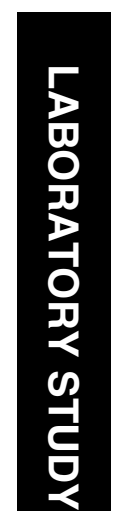

${ }^{1}$ Department of Ophthalmology, Taoyuan Veterans Hospital, Taoyuan, Taiwan

${ }^{2} J$ ules Stein Eye Institute and Department of Ophthalmology, University of California, Los Angeles, CA, USA

${ }^{3}$ Department of Ophthalmology, National Yang-Ming University and Taipei Veterans General Hospital, Taipei, Taiwan

${ }^{4}$ Institute of Clinical Medicine, National Yang-Ming University, Taipei, Taiwan

\section{${ }^{5}$ Department of} Biochemistry and Molecular Biology, National Yang-Ming University, Taipei, Taiwan

${ }^{6}$ Department of Ophthalmology, Cheng Hsin Rehabilitation Medical Center, Taipei, Taiwan

Correspondence: Y-H Wei, Department of Biochemistry, School of Medicine, National Yang-Ming University, 155 Li-Nong St., Sec.2, Taipei 112, Taiwan Tel: + 886228267118 ; Fax: + 886228264843 . E-mail: joeman@ ym.edu.tw

Received: 28 March 2005 Accepted in revised form: 30 June 2005; Published online: 19 August 2005

\title{
Increased oxidative DNA damage, 8-hydroxydeoxy- guanosine, in human pterygium
}

\begin{abstract}
Purpose Chronic exposure to ultraviolet (UV) light is a widely accepted aetiological factor in the development of pterygium. UV radiation may induce production of reactive oxygen species via photosensitized oxidation, thus causing oxidative damage. This study was conducted to test the hypothesis that oxidative damage to DNA is increased in pterygium.

Methods Immunohistochemical analysis employing a monoclonal antibody specific for 8-hydroxy-2'-deoxyguanosine (8-OHdG), a ubiquitous maker of oxidative stress, was performed in three patients with primary pterygium. The levels of 8-OHdG in DNA isolated from the other 29 pterygium specimens and their adjacent normal conjunctival tissues were determined using
\end{abstract} enzyme-linked immunosorbent assay (ELISA). Results Immunohistochemistry of 8-OHdG showed a distinct pattern of more extensive and intense staining in the nuclei of pterygium tissue compared with that in their adjacent normal conjunctiva. ELISA also revealed that the average level of 8-OHdG in the pterygium tissues was 4.7 -fold higher than that of the corresponding normal conjunctiva $(P<0.001)$.

Conclusions The increased levels of 8-OHdG in the pterygium tissues indicate that oxidative stress could play a role in the development of pterygium. These findings provide new information to better understand the pathogenesis of pterygium and are useful in the prevention and treatment of this disease.

Eye (2006) 20, 826-831. doi:10.1038/sj.eye.6702064; published online 19 August 2005

Keywords: DNA; 8-hydroxydeoxyquanosine; pterygium; ultraviolet
H-C Kau ${ }^{1,2,3}$, C-C Tsai, ${ }^{3,4}$, C-F Lee ${ }^{5}$, S-C Kao ${ }^{3}$, W-M Hsu' ${ }^{3}, \mathrm{~J}-\mathrm{H} \mathrm{Liu}{ }^{3,6}$ and $\mathrm{Y}-\mathrm{H} \mathrm{Wei}^{5}$

\section{Introduction}

Pterygium, a wing-shaped (pterygos in Greek is wing) fibrovascular growth of conjunctiva extending into the superficial cornea, may cause irritation, redness, and tearing. As the pterygium develops, it may alter the shape of the cornea to cause astigmatism, or grow over the central cornea to threaten the vision. Several factors have been proposed to play a role in the pathogenesis of pterygium, such as antiapoptosis, proinflammatory cytokines, growth factors, immunological responses, viral infections, extracellular matrix remodelling, and genetic factors. ${ }^{1}$ Although the detailed molecular mechanism remains unclear, it has been widely accepted that chronic ultraviolet (UV) exposure is a major aetiological factor, which is supported by epidemiological evidence, ${ }^{2,3}$ the ray tracing model, ${ }^{4}$ and the similar histopathological features in pterygium and UV-damaged skin. ${ }^{5,6}$ The noxious effects of UV radiation are either caused by direct UV radiation or by indirect stress via reactive oxygen species (ROS). ${ }^{7}$ Excess ROS can overwhelm the antioxidant system and cause oxidative damage to a variety of biological molecules such as lipids, proteins, and DNA. Lu $e t \mathrm{al}^{8}$ had demonstrated ROS-induced lipid peroxidation in the pterygium tissue. However, very limited information is available regarding the oxidative DNA damage in pterygium.

In a previous study, we showed that patients with Ser326Cys polymorphism of 8-oxoguanine glycosylase I (hOGG1) were more susceptible to pterygium formation. ${ }^{9}$ hOGG1 is a key enzyme responsible for the base excision repair of 8-hydroxy-2'-deoxyguanosine (8-OHdG). ROS produced by UVB and UVA radiation through photosensitized oxidation can target DNA base guanine, giving rise to 8-OHdG in DNA molecules. ${ }^{10} 8$-OHdG has been shown to be a 
sensitive and stable biomarker for evaluating the degree of oxidative DNA damage. ${ }^{11}$ Based on these findings, we further hypothesized that oxidative damage to DNA is increased in pterygium tissues. In this study, immunohistochemical staining using a monoclonal antibody to 8-OHdG was performed to compare the distribution of $8-\mathrm{OHdG}$ in pterygium tissues and their corresponding normal conjunctiva. In addition, we provide novel data to further demonstrate that the average level of $8-\mathrm{OHdG}$ in pterygium tissues is higher than that of normal conjunctiva by enzyme-linked immunosorbent assay (ELISA).

\section{Materials and methods}

\section{Tissue sampling}

Excised primary pterygia and their corresponding adjacent normal conjunctival tissues located under lower eyelid margin from 32 eyes of 32 patients were obtained at surgery from the Taipei Veterans General Hospital, Taiwan. Diagnosis of pterygium was established according to the clinical finding of a wing-shaped fold of conjunctiva and fibrovascular tissue that had invaded the adjacent cornea for which there was no alternative explanation (eg, trauma). All tissue specimens were collected and immediately stored in cryovials with nitrogen substitution and kept in a refrigerator at $-70^{\circ} \mathrm{C}$ until use. Immunohistochemical analysis of $8-\mathrm{OHdG}$ was conducted in the first three patients, and the $8-\mathrm{OHdG}$ levels were measured by ELISA in the other 29 patients. Informed consent was obtained from each subject and the experimental protocol was approved by the Institutional Review Board of Taipei Veterans General Hospital and performed in accordance with the tenets of the Declaration of Helsinki.

\section{Immunohistochemical analysis}

The avidin-biotin-peroxidase complex method was first used to determine the content of $8-\mathrm{OHdG} .{ }^{12}$ The pterygium tissues were fixed in Bouin's solution for $2 \mathrm{~h}$, sequentially immersed in 50 and $70 \%$ ethanol, and followed by dehydration. Specimens were then embedded in paraffin, sectioned at $4 \mu \mathrm{m}$, and mounted on glass slides coated with poly-L-lysine. After being heated in a microwave for $10 \mathrm{~min}$ to enhance epitope expression, the specimens were treated with normal rabbit serum (Dako, Kyoto, Japan; diluted 1:75) to block nonspecific binding and then incubated with monoclonal antibody N45.1 (Japan Institute for the Control of Aging, Fukuroi, Japan; $2.5 \mu \mathrm{g} / \mathrm{ml}$ ), followed by addition of biotin-labelled rabbit anti-mouse IgG serum (Dako, Kyoto, Japan; diluted 1:300). Endogenous peroxidase was blocked by treating the specimens with $3 \%$ hydrogen peroxide in methanol for $30 \mathrm{~min}$. After washing with $50 \mathrm{mM}$ Tris- $\mathrm{HCl}$ buffer ( $\mathrm{pH} 8.0$ ), the antigen-antibody complexes in specimens were visualized using a streptavidin-horseradish peroxidase detection system (Dako, Kyoto, Japan) with diaminobenzidine as chromogen.

\section{Quantitative analysis of 8-OHdG}

The DNA in each specimen was obtained by using the DNA Extractor Kit (Wako Pure Chemical Industries Inc., Osaka, Japan) according to the manufacturer's instructions. To eliminate the production of iatrogenic 8-OHdG, the container had nitrogen substituted through the entire procedure. After extraction, the DNA was dissolved in $60 \mu \mathrm{l}$ DNase-free water and stored at $-70^{\circ} \mathrm{C}$ until use. Of the DNA solution, $10 \mu \mathrm{l}$ was used for measurement of DNA concentration using the PicoGreen dsDNA Quantitation Kit (Molecular Probes, Eugene, OR, USA).

The rest of the extracted DNA solution was digested with nuclease P1 (Roche, Mannheim, Germany) in a solution of $200 \mathrm{mM}$ sodium acetate ( $\mathrm{pH}$ 5.3), followed by treatment with alkaline phosphatase (Roche, Mannheim, Germany) in $1 \mathrm{M}$ Tris- $\mathrm{HCl}$ buffer ( $\mathrm{pH}$ 7.4). To remove enzymes and other macromolecules, the hydrolysate was filtrated through the Ultrafree Centrifugal Filter C3LGC (Millipore, Billerica, MA, USA) at $10000 \mathrm{~g}$ for $10 \mathrm{~min}$ at $4^{\circ} \mathrm{C}$.

The content of $8-\mathrm{OHdG}$ in each sample was determined by using the highly sensitive 8-OHdG ELISA kit (Japan Institute for the Control of Aging, Fukuroi, Japan) according to the manufacturer's instructions. The detection range was $0.125-10 \mathrm{ng} / \mathrm{ml}$. ELISA method is more simple and easier than high-performance liquid chromatography with electrochemical detection (HPLCECD) with respect to the equipment, analysis time, running cost, and sample volume. The results of the ELISA test correlated well with the data obtained from measurement by HPLC-ECD. ${ }^{13}$

\section{Statistical analysis}

Data were analysed using an SPSS statistical package, version 10.0 (SPSS Inc., Chicago, IL, USA). Comparison of $8-\mathrm{OHdG}$ contents between pterygium and normal conjunctival tissue was performed by means of the Wilcoxon signed-rank test. The comparison of the 8-OHdG content in pterygium between different genders was performed by the Wilcoxon rank-sum test. The correlation coefficient between age and the 8 -OHdG content in pterygium was calculated. $P<0.05$ was considered to be of statistical significance. 


\section{Results}

\section{Immunohistochemical detection of 8-OHdG}

Immunohistochemical analysis of $8-\mathrm{OHdG}$ was conducted in the first three pterygium cases and reproducible results were obtained. Representative results of one case are shown in Figure 1. Strong immunoreactivity was observed in the whole layer of pterygium epithelium and scantly distributed in the subepithelial stroma (Figure 1a). There was an intense and coarse granular staining pattern in the nuclei of pterygium tissue. In contrast, the immunoreactivity in
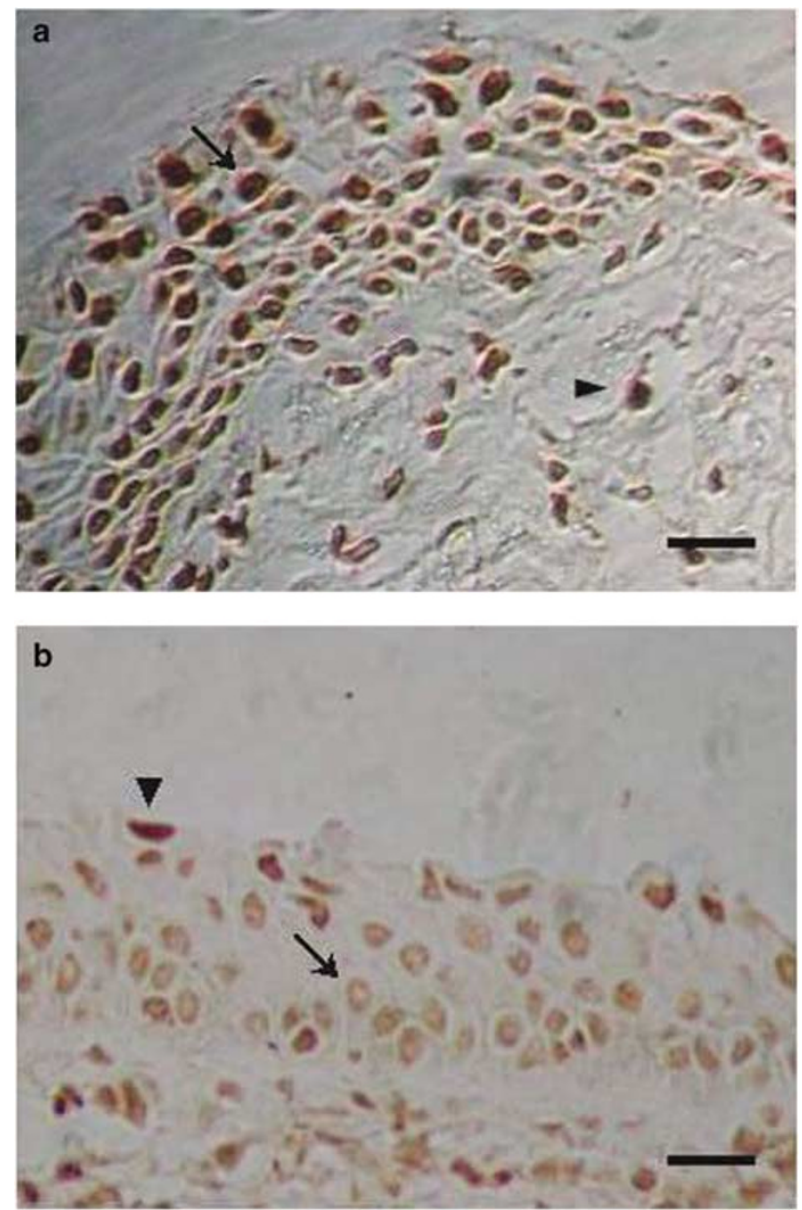

Figure 1 Immunohistochemical staining for 8-OHdG in pterygium tissue and normal conjunctiva. (a) Strong immunoreactivity was observed in the whole layer of pterygium epithelium and scantly distributed in the subepithelial stroma (arrowhead), revealing an intense and coarse granular staining pattern in the nuclei (arrow). (b) In contrast, the immunoreactivity in normal conjunctival epithelium and stromal layer was weak, showing a faint and small spherical staining pattern near the nuclear membrane (arrow). Some strong staining nuclei were occasionally seen in the superficial layer of normal conjunctival epithelium (arrowhead). Scale bars in (a) and (b) represent $20 \mu \mathrm{m}$. normal conjunctival epithelium and stromal layer was weak, and showed a faint and small spherical staining pattern near the nuclear membrane (Figure 1b).

\section{Determination of 8-OHdG content}

The demographic information and the 8-OHdG content in the pterygium tissues of the 29 patients are summarized in Table 1 . The mean value of $8-\mathrm{OHdG}$ content was $53.93 \pm 8.17 \mathrm{ng}$ of $8-\mathrm{OHdG}$ per mg DNA in pterygium tissues and $11.40 \pm 0.80 \mathrm{ng}$ of $8-\mathrm{OHdG}$ per $\mathrm{mg}$ DNA in the adjacent normal conjunctiva (Figure 2). The average level of $8-\mathrm{OHdG}$ in pterygium tissues was 4.7-fold higher than that in the normal conjunctiva $(P<0.001)$. However, the $8-\mathrm{OHdG}$ content in the pterygium tissue was not related to the $\operatorname{sex}(P=0.753)$ or age $(P=0.817)$ of the patient.

\section{Discussion}

In the current study, we demonstrated abundant immunoreactivity of $8-\mathrm{OHdG}$ in pterygium tissues and

Table 1 Demography and 8-OHdG content in pterygium tissues of 29 patients

\begin{tabular}{|c|c|c|c|c|}
\hline \multirow[t]{2}{*}{ Case } & \multirow[t]{2}{*}{ Sex } & \multirow[t]{2}{*}{ Age } & \multicolumn{2}{|c|}{ 8-OHdG content ( $\mathrm{ng} / \mathrm{mg} \mathrm{DNA}$ ) } \\
\hline & & & Pterygium & $\begin{array}{c}\text { Normal } \\
\text { conjunctiva }\end{array}$ \\
\hline 1 & $\mathrm{~F}$ & 54 & 189.47 & 12.71 \\
\hline 2 & M & 70 & 130.45 & 10.01 \\
\hline 3 & M & 69 & 30.98 & 11.82 \\
\hline 4 & $\mathrm{~F}$ & 65 & 38.18 & 7.87 \\
\hline 5 & M & 71 & 26.81 & 5.78 \\
\hline 6 & M & 70 & 99.69 & 11.11 \\
\hline 7 & M & 70 & 41.62 & 12.59 \\
\hline 8 & M & 68 & 15.93 & 10.07 \\
\hline 9 & M & 82 & 64.04 & 6.19 \\
\hline 10 & M & 72 & 159.49 & 15.11 \\
\hline 11 & $\mathrm{~F}$ & 68 & 52.41 & 10.33 \\
\hline 12 & $\mathrm{~F}$ & 70 & 101.62 & 11.82 \\
\hline 13 & $\mathrm{~F}$ & 73 & 23.31 & 6.78 \\
\hline 14 & M & 73 & 17.13 & 20.11 \\
\hline 15 & M & 80 & 51.62 & 12.59 \\
\hline 16 & $\mathrm{~F}$ & 44 & 39.68 & 8.43 \\
\hline 17 & M & 83 & 25.82 & 20.83 \\
\hline 18 & $\mathrm{~F}$ & 66 & 27.32 & 8.56 \\
\hline 19 & $\mathrm{~F}$ & 57 & 29.21 & 9.07 \\
\hline 20 & M & 65 & 42.98 & 8.74 \\
\hline 21 & M & 67 & 77.78 & 10.07 \\
\hline 22 & M & 70 & 19.45 & 8.83 \\
\hline 23 & $\mathrm{~F}$ & 65 & 25.32 & 9.72 \\
\hline 24 & $\mathrm{~F}$ & 49 & 17.64 & 18.43 \\
\hline 25 & $\mathrm{M}$ & 70 & 28.53 & 13.25 \\
\hline 26 & M & 74 & 18.34 & 22.24 \\
\hline 27 & $\mathrm{M}$ & 78 & 56.22 & 11.20 \\
\hline 28 & M & 85 & 75.93 & 6.07 \\
\hline 29 & $\mathrm{~F}$ & 78 & 36.88 & 10.21 \\
\hline
\end{tabular}




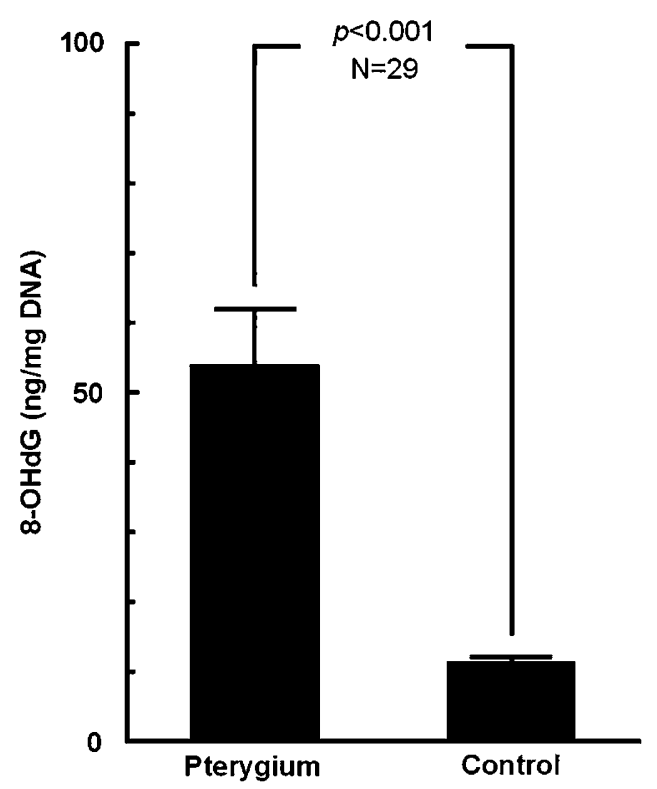

Figure 2 The mean 8-OHdG content in DNA from the pterygium tissues is higher than that of the adjacent normal conjunctiva.

significantly higher levels of 8-OHdG in the DNA of pterygium tissues as compared to its adjacent normal conjunctiva. This finding supports the idea that oxidative damage to DNA may play a role in the development of pterygium.

The pathogenesis of pterygium is not clearly understood. Recent studies have provided evidence indicating that pterygium has both degenerative and proliferative characteristics. The degenerative nature of pterygium revealed from light and electron microscopic examinations showed elastotic degeneration of collagen fibres, activated fibroblasts, and inflammatory infiltrate that resembles the actinic degenerative changes seen in the skin exposed to chronic UV radiation. ${ }^{5,6,14}$ On the other hand, the epithelium of pterygium may display squamous metaplasia. ${ }^{15}$ In addition, adjunctive alkylating antineoplastic agent or radiotherapy is usually required to prevent the high recurrent rate in the treatment of pterygium. ${ }^{16,17}$ Furthermore, the presence of oncogenic viruses, ${ }^{18}$ loss of heterozygosity, ${ }^{19}$ and abnormal expression of p53 in pterygium tissues ${ }^{20}$ suggest possible neoplastic nature of pterygium.

Oxidative stress induced by either environmental agents or endogenous biochemical reactions has been implicated in the pathogenesis of a variety of degenerative and proliferative diseases. ${ }^{21-23}$ As a reliable biomarker of oxidative DNA damage, higher levels of 8-OHdG have been observed in the lungs of cigarette smokers, ${ }^{24}$ the liver of patients with chronic hepatitis, ${ }^{25}$ the breast tissue of benign and malignant tumors, ${ }^{26}$ the trabecular meshwork of glaucoma patients, ${ }^{27}$ the renalcell carcinoma, ${ }^{28}$ the urine of patients with dystrophinopathy, ${ }^{29}$ the leucocytes of patients with Leber's hereditary optic neuropathy ${ }^{30}$ and patients on chronic hemodialysis, ${ }^{31}$ and heart mitochondrial DNA of patients with atrial fibrillation. ${ }^{32}$ To our knowledge, this is the first study to explore the increase of $8-\mathrm{OHdG}$ content in pterygium tissue.

Apart from the direct DNA damage, oxidative stress has been shown to regulate gene expression by modulating transcription factors, which then induce the expression of various proinflammatory cytokines, angiogenic, and fibrogenic factors. ${ }^{33}$ Several reports pointed out the presence of these cytokines and growth factors and/or their receptors in pterygium tissues; in addition, their presence could also be induced by UV irradiation. ${ }^{34-37}$ These evidences suggest that oxidative stress and oxidative damage, especially caused by UV irradiation, may contribute to the pathogenesis of pterygium.

The 8 -OHdG frequently mispairs with adenine during DNA replication, which leads to G-C to T-A transversion, ultimately gives rise to gene mutation. ${ }^{38}$ A number of defense and repair mechanisms have evolved to minimize its accumulation within the genome. Primary defense mechanisms include antioxidants and free radical-scavenging enzymes. Once 8-OHdG is formed, the hOGG1 enzyme, a DNA glycosylase/apurinic lyase, is expressed and involved in the base excision repair of 8-OHdG. Previous studies have revealed a common polymorphism in the hOGG1 gene of functional difference. It has been proved by using an Escherichia coli complementation assay that the DNA repair activity of hOGG1-Cys ${ }^{326}$ is lower than that of hOGG1-Ser ${ }^{326} \cdot{ }^{39}$ This genetic polymorphism of hOGG1 is associated with the risk of many kinds of neoplasia and high degree of oxidative DNA damage in patients suffering from chronic oxidative stress. ${ }^{40,41}$ Our previous study has shown that individuals who carried the homozygous Cys/Cys genotype were at a 2.2-fold higher risk to develop pterygium. Besides, the patients with Cys/Cys genotype were younger than those with other two genotypes combined (Cys/Ser and Ser/Ser) in the pterygium group. ${ }^{9}$ It is suggested that subjects with the Cys326 allele may have more accumulative oxidative damages and thus are more prone to develop pterygium. Our current findings further proved that there was significant higher oxidative DNA damage in pterygium tissue. However, further studies are warranted to provide more information about the role of hOGG1 and 8 -OHdG in the pathogenesis of pterygium.

In conclusion, our study demonstrated increased oxidative damage to DNA in human pterygium tissues. These findings shed new light to better understanding of 
the pathogenesis of pterygium and may be useful in the prevention and treatment of this disease.

\section{Acknowledgements}

We express our appreciation of Mr Yi-Shing Ma and Ms Tzu-Ling Chen for their technical assistance. This study was supported by a Grant (NSC92-2320-B-010-037) from the National Science Council of Taiwan. None of the authors have any commercial interest in the materials mentioned herein.

\section{References}

1 Di Girolamo N, Chui J, Coroneo MT, Wakefield D. Pathogenesis of pterygia: role of cytokines, growth factors, and matrix metalloproteinases. Prog Retin Eye Res 2004; 23: 195-228.

2 Threlfall TJ, English DR. Sun exposure and pterygium of the eye: a dose-response curve. Am J Ophthalmol 1999; 128: 280-287.

3 Wong TY, Foster PJ, Johnson GJ, Seah SK, Tan DT. The prevalence and risk factors for pterygium in an adult Chinese population in Singapore: the Tanjong Pagar survey. Am J Ophthalmol 2001; 131: 176-183.

4 Kwok LS, Coroneo MT. A model for pterygium formation. Cornea 1994; 13: 219-224.

5 Austin P, Jakobiec FA, Iwamoto T. Elastodysplasia and elastodystrophy as the pathologic bases of ocular pterygia and pinguecula. Ophthalmology 1983; 90: 96-109.

6 Fligiel SE, Varani J, Datta SC, Kang S, Fisher GJ, Voorhees JJ. Collagen degradation in aged/photodamaged skin in vivo and after exposure to matrix metalloproteinase- 1 in vitro. J Invest Dermatol 2003; 120: 842-848.

7 Ichihashi M, Ueda M, Budiyanto A, Bito T, Oka M, Fukunaga M et al. UV-induced skin damage. Toxicology 2003, 189: 21-39.

8 Lu L, Wang R, Song X. Pterygium and lipid peroxidation. Chin J Ophthalmol 1996; 32: 227-229.

9 Kau HC, Tsai CC, Hsu WM, Liu JH, Wei YH. Genetic polymorphism of hOGG1 and risk of pterygium in Chinese. Eye 2004; 18: 635-639.

10 Cadet J, Douki T, Pouget JP, Ravanat JL. Singlet oxygen DNA damage products: formation and measurement. Methods Enzymol 2000; 319: 143-153.

11 Kasai H. Analysis of a form of oxidative DNA damage, 8-hydroxy-2'- deoxyguanosine, as a marker of cellular oxidative stress during carcinogenesis. Mutat Res 1997; 387: 147-163.

12 Hsu SM, Raine L, Fanger H. Use of avidin-biotinperoxidase complex $(\mathrm{ABC})$ in immunoperoxidase techniques: a comparison between $\mathrm{ABC}$ and unlabeled antibody (PAP) procedures. J Histochem Cytochem 1981; 29: 577-580.

13 Yoshida R, Ogawa Y, Kasai H. Urinary 8-oxo-7,8-dihydro-2'deoxyguanosine values measured by an ELISA correlated well with measurements by high-performance liquid chromatography with electrochemical detection. Cancer Epidemiol Biomarkers Prevent 2002; 11: 1076-1081.

14 Cameron ME. Histology of pterygium: an electron microscopic study. Br J Ophthalmol 1983; 67: 604-608.
15 Wang IJ, Lai WT, Liou SW, Chiu CZ, Hu FR, Kao WW et al. Impression cytology of pterygium. J Ocular Pharmacol Therap 2000; 16: 519-528.

16 Lam DS, Wong AK, Fan DS, Chew S, Kwok PS, Tso MO. Intraoperative mitomycin $C$ to prevent recurrence of pterygium after excision: a 30-month follow-up study. Ophthalmology 1998; 105: 901-904.

17 Jurgenliemk-Schulz IM, Hartman LJ, Roesink JM et al. Prevention of pterygium recurrence by postoperative single-dose beta-irradiation: a prospective randomized clinical double-blind trial. Int J Radiat Oncol Biol Phys 2004; 59: 1138-1147.

18 Detorakis ET, Sourvinos G, Spandidos DA. Detection of herpes simplex virus and human papilloma virus in ophthalmic pterygium. Cornea 2001; 20: 164-167.

19 Detorakis ET, Sourvinos G, Tsamparlakis J, Spandidos DA. Evaluation of loss of heterozygosity and microsatellite instability in human pterygium: clinical correlations. $\mathrm{Br} \mathrm{J}$ Ophthalmol 1998; 82: 1324-1328.

20 Weinstein O, Rosenthal G, Zirkin H, Monos T, Lifshitz T, Argov S. Overexpression of p53 tumor suppressor gene in pterygia. Eye 2002; 16: 619-621.

21 Wei YH. Oxidative stress and mitochondrial DNA mutations in human aging. Proc Soc Exp Biol Med 1998; 217: 53-63.

22 Giacosa A, Filiberti R. Free radicals, oxidative damage and degenerative diseases. Eur J Cancer Prev 1996; 5: 307-312.

23 Kawanishi S, Hiraku Y, Oikawa S. Mechanism of guaninespecific DNA damage by oxidative stress and its role in carcinogenesis and aging. Mutat Res 2001; 488: 65-76.

24 Asami S, Manabe H, Miyake J, Tsurudome Y, Hirano T, Yamaguchi $\mathrm{R}$ et al. Cigarette smoking induces an increase in oxidative DNA damage, 8-hydroxydeoxyguanosine, in a central site of the human lung. Carcinogenesis 1997; 18: 1763-1766.

25 Shimoda R, Nagashima M, Sakamoto M, Yamaguchi N, Hirohashi S, Yokota J et al. Increased formation of oxidative DNA damage, 8-hydroxydeoxyquanosine, in human livers with chronic hepatitis. Cancer Res 1994; 54: 3171-3172.

26 Musarrat J, Arezina-Wilson J, Wani AA. Prognostic and aetiological relevance of 8-hydroxyguanosine in human breast carcinogenesis. Eur J Cancer 1996; 32: 1209-1214.

27 Izzotti A, Sacca SC, Cartiglia C, De Flora S. Oxidative deoxyrinonucleic acid damage in the eyes of glaucoma patients. Am J Med 2003; 114: 638-646.

28 Okamoto K, Toyokuni S, Uchida K, Ogawa O, Takenewa J, Kakehi $Y$ et al. Formation of 8-hydroxy-2'-deoxyguanosine and 4-hydroxy-2-nonenal-modified proteins in human renal-cell carcinoma. Int J Cancer 1994; 58: 825-829.

29 Rodriguez MC, Tarnopolsky MA. Patients with dystrophinopathy show evidence of increased oxidative stress. Free Radic Biol Med 2003; 34: 1217-1220.

30 Yen MY, Kao SH, Wang AG, Wei YH. Increased 8-hydroxy2'-deoxyguanosine in leukocyte DNA in Leber's hereditary optic neuropathy. Invest Ophthalmol Vis Sci 2004; 45: 1688-1691.

31 Tarng DC, Huang TP, Wei YH, Liu TY, Chen HW, Wen Chen T et al. 8-hydroxy-2'-deoxyguanosine of leukocyte DNA as a marker of oxidative stress in chronic hemodialysis patients. Am J Kidney Dis 2000; 36: 934-944.

32 Lin PH, Lee SH, Su CP, Wei YH. Oxidative damage to mitochondrial DNA in atrial muscle of patients with 
atrial fibrillation. Free Radic Biol Med 2003; 35:

1310-1318

33 Eyries M, Collins T, Khachigian L. Modulation of growth factor gene expression in vascular cells by oxidative stress. Endothelium 2004; 11: 133-139.

34 Kria L, Ohira A, Amemiya T. Immunohistochemical localization of basic fibroblast growth factor, platelet derived growth factor, transforming growth factor-beta and tumor necrosis factor-alpha in the pterygium. Acta Histochem 1996; 98: 195-201.

35 Lee DH, Cho HJ, Kim JT, Choi JS, Joo CK. Expression of vascular endothelial growth factor and inducible nitric oxide synthase in pterygia. Cornea 2001; 20: 738-742.

36 Di Girolamo N, Kumar RK, Coroneo MT, Wakefield D. UVB-mediated induction of interleukin- 6 and -8 in pterygia and cultured human pterygium epithelial cells. Invest Ophthalmol Vis Sci 2002; 43: 3430-3437.

37 Nolan TM, DiGirolamo N, Sachdev NH, Hampartzoumian T, Coroneo MT, Wakefield D. The role of ultraviolet irradiation and heparin-binding epidermal growth factor- like growth factor in the pathogenesis of pterygium. Am J Pathol 2003; 162: 567-574.

38 Cheng KC, Cahill DS, Kasai H, Nishimura S, Loeb LA. 8-Hydroxyguanine, an abundant form of oxidative DNA damage, causes $\mathrm{G} \rightarrow \mathrm{T}$ and $\mathrm{A} \rightarrow \mathrm{C}$ substitutions. J Biol Chem 1992; 267: 166-172.

39 Kohno T, Shimura K, Tosaka M, Tani M, Kim SR, Sugimura $\mathrm{H}$ et al. Genetic polymorphisms and alternative splicing of the hOGG1 gene, that is involved in the repair of 8-hydroxyguanine in damaged DNA. Oncogene 1998; 16: 3219-3225.

40 Le Marchand L, Donlon T, Lum-Jones A, Seifried A, Wilkens LR. Association of the hOGG1 Ser326Cys polymorphism with lung cancer risk. Cancer Epidemiol Biomarkers Prevent 2002; 11: 409-412.

41 Tarng DC, Tsai TJ, Chen WT, Liu TY, Wei YH. Effect of human OGG1 $1245 \mathrm{C} \rightarrow \mathrm{G}$ gene polymorphism on 8-hydroxy-2'-deoxyguanosine levels of leukocyte DNA among patients undergoing chronic hemodialysis. J Am Soc Nephrol 2001; 12: 2338-2347. 